\title{
The Development of Knowledge Enrichment Books Concerning Ice and Snow Physical Studies for High- School Students
}

\author{
Slamet Maulana ${ }^{1, \mathrm{a})}$, Desnita $^{2, \mathrm{~b})}$, Raihanati ${ }^{1}$ \\ ${ }^{1}$ Physics Education Study Program, Faculty of Mathematics and Natural Sciences, \\ Universitas Negeri Jakarta, Rawamangun Muka Street, Jakarta 13220 \\ ${ }^{2}$ Physics Education Study Program, Faculty of Mathematics and Natural Sciences, \\ Universitas Negeri Padang, Prof DR Hamka Street, Padang, Sumatera Barat 25131 \\ $\bowtie:{ }^{\text {a)}}$ slametmaulana1996@gmail.com, b) desywaznadil@gmail.com
}

\begin{abstract}
This research aims to develop a knowledge-enrichment physics book of ice and snow that is worthy of use as an enrichment material on physics subject. This research is a research and development with an ADDIE (Analysis, Design, Development, Implementation, and Evaluation) model. The developed book referred from the Central of Curriculum and Book guideline so that the developed book can be recommended as enrichment material for highschool students. The developed book uses communicative language, attractive illustrations, and information concerning ice and snow with updated science knowledge. The result by physics expert on the developed enrichment book is $94.12 \%$ with a category "very good," media expert $87.50 \%$ with a category "very good," and with the same category is also given by education expert who gave a score $92.04 \%$. The result of the product trial test shows that students accept the developed enrichment books with "very good," which represent an average score of $90.06 \%$. Based on the validation and product trials test, it concluded that the enrichment book titled "Ice and Snow" are worthy to be used as enrichment materials on physics.
\end{abstract}

Keywords: research and development, knowledge-enrichment book, ice and snow

\section{INTRODUCTION}

According to Minister of National Education Number 2 of 2008 concerning Books, article 6 paragraph (2) which states that in addition to textbooks, educators can use educator guidebooks, enrichment books, and reference books in the learning process. Furthermore, it is reaffirmed in paragraph (3) which states that to increase students' knowledge and insight, educators can encourage students to read enrichment books and reference books (Government of National Education).

Educators can encourage students to read enrichment books and reference books to increase students' knowledge and insight. It includes enrichment activities as a follow up to the learning process. Enrichment books have an essential role in teaching and learning activities (Andriani 2018, 27). The development of enrichment books is important, besides being used to add insight and knowledge, it is also used to supplement the textbooks used in schools (Jayanti 2015, 66).

Enrichment is an effort to help students who have achieved mastery learning to broaden their knowledge and skills (Izzati 2015, 58). Enrichment programs can be activities, experiences, and subject matter that bring students outside the regular curriculum, challenge their abilities and fulfill 
their curiosity, and fill their time. Enrichment programs mean giving students the opportunity to study material more deeply than what is done in class (Al-Zoubi 2014, 23). Besides that, offering enrichment programs can also develop students' thinking skills (Sanova 2017, 59).

Enrichment books can be used as learning resources that support the learning process (Astra 2018, 2). If the use of enrichment books in schools is optimized, students will be able to follow the development of communication and technology in the present very well (Maryam 2012, 48). The enrichment book contains material that can enrich and enhance mastery of science, technology and art and skills, shape the personality of students, educators, education managers, and other communities (Center for Curriculum and Bookkeeping 2014). The enrichment books are books that contain material that can enrich and enhance mastery of science and technology, skills, and shape the personality of students, educators, education managers, and other readers (Mariana and Graduates $2018,51)$. The characteristic of enrichment books is that the material does not have to be directly tied to the curriculum; the target readers are not explicitly limited despite the appearance and content aspects of the readability of readers imaginable; presentations can be prose with pictures; generally use popular language; material grows and develops cognitive aspects, skills, attitudes, morals, and personalities (Ernawati and Ikhsan 2017, 3). The content in the enrichment book must also be adapted to the environment of the students so that students are easy to learn because it is related to the environment and daily life (Rediati 2015,4). Learning enrichment books should also focus on moral / character education (Fahmi 2015, 88). So based on the descriptions above, the role of enrichment books in the learning process is crucial, not only able to increase students' knowledge but also able to develop an affective and psychomotor aspects of students.

Enrichment books grouped into three, namely knowledge enrichment books, skill enrichment books, and personality enrichment books. Knowledge enrichment books are books that contain material that can enrich and enhance mastery of science and technology. Knowledge enrichment books function as readings of students, educators, education managers, and other communities so that they can enrich and enhance mastery of science and technology. Knowledge enrichment books are books intended for students to improve their knowledge and understanding, both outward knowledge and inner knowledge (Center of Curriculum and Books 2014). The features of the knowledge enrichment book are presenting material that is a reality, develops reading material that is based on science, and develops various knowledge such as factual knowledge, conceptual knowledge, procedural knowledge, and metacognitive knowledge.

Even so, the use of enrichment books is still not optimal in enriching students' knowledge. The availability of enrichment books at school is still not sufficient. Based on a survey conducted on the existence of a Physics enrichment book in many schools data was obtained as follows.

TABLE 1. List of Enrichment Book in Some Schools

\begin{tabular}{cl}
\hline & \multicolumn{1}{c}{ Book Title } \\
\hline 1 & Menyelamatkan Samudra dan Lahan Basah \\
2 & Satwa dalam Bahaya \\
3 & Pemanasan Global \\
4 & Pencemaran \\
5 & Kemagnetan \\
6 & Optika Geometri \\
7 & Getaran dan Gelombang \\
8 & Planet Bumi \\
9 & Kehidupan di Bumi \\
10 & Alam Semesta \\
\hline
\end{tabular}

Ice and snow are environmental phenomena that are familiar to the community. In Indonesia, ice found everywhere while snow is only in a few countries. Therefore, insights regarding ice and snow also need to be given to students. However, from some school libraries that had been surveyed, no books were found that discussed ice and snow.

Based on the descriptions above, the knowledge enrichment book needs to be developed with several reasons as follows: (1) Availability of minimal enrichment books in schools, (2) The absence of a book on the enrichment of physical knowledge that addresses physical studies of the 
phenomenon of ice and snow in life everyday explicitly. So the researchers decided to develop an enrichment book on physics knowledge that discussed physical studies on the phenomenon of ice and snow to enrich students' knowledge about the phenomenon of ice and snow in everyday life.

\section{RESEARCH METHODOLOGY}

This research will use a research and development model. The research and development carried out will refer to the stages of the ADDIE development model. Research and development of ADDIE models are often used in research and teaching materials such as modules, worksheets, and textbooks (Mulyatiningsih 2011, 179). The development research carried out is the process used to develop and validate educational products. Educational products that will be developed in the form of enrichment books. Books that have been developed will then be tested for feasibility by material experts, media, and learning.

Furthermore, books that have been developed will be piloted in the field. Data obtained from questionnaires for feasibility testing and product testing were analyzed by simple quantitative analysis techniques using Likert scale calculations with points 1 to 4 . The Likert scale is used to measure the attitudes, opinions, and perceptions of a person or group of people about social phenomena (Ary 2010, 209).

The analysis was carried out to identify the problems and needs of the students in physics learning and to know the materials accordance with the books developed. The first analysis is to obtain information related to the existence of enrichment books by conducting surveys in some school libraries and bookstores. Based on the study conducted, the presence of enrichment books is still limited. The next analysis is curriculum analysis, where this analysis is carried out to obtain information related to the implementation of the curriculum in schools. At present schools in Indonesia have implemented the 2013 curriculum. The last analysis is analysis through literature studies of books and literature on ice and snow.

After carrying out the stages of analysis, the next step is to design. At this stage, design of learning media be developed. Concepts and materials are designed by compiling material outlines. The drafting was done by looking for literacy sources related to ice and snow material.

The third stage is the stage of development. After the literature study, the outline and discussion are arranged in a general flow to specific. In making the reader active and motivated to continue reading, several components are produced that contain major events, scientific vocabulary, or interesting facts related to ice and snow. To enrich the visual aspects of enrichment books, the collection of images, photographs or illustrations related to the material is also carried out.

After the enrichment book has been developed, the next step is implementation. This stage is the stage of applying the initial design of the knowledge enrichment book and testing its feasibility to physicists, media, learning before being tested to high school students of class XI with the aim of obtaining input and improving the knowledge enrichment book made as the final product. Knowledge enrichment books that have been completed have been tried out to several physicists, media, learning, and graphics to obtain data and corrections. Then the data is processed and revised according to data analysis as material for revision evaluation of the development of further knowledge enrichment books. Testing of knowledge enrichment books is done by questionnaire testing or in other words the device used is a validated instrument for physicists, media experts, and learning experts referring to Central of Curriculum and Book.

The last step is the evaluation. At this stage, the product was evaluated as a form of revision from several physicists, media, and learning. After correction, the product is ready to be tested to high school students of class XI through questionnaires to determine the acceptability and feasibility of the product, so that the final product can be assessed and decided whether or not the feasibility of the knowledge enrichment book to be used or not. If the results of the research are improved in the form of knowledge enrichment books that show good and feasible results, it can be used as a final product for the knowledge enrichment book "Ice and Snow " for high school students. 


\section{RESULTS AND DISCUSSION}

\section{Results}

The product of this development research is a book enriching the knowledge of physical studies of ice and snow. This enrichment book consists of five chapters namely: (1) Chapter I Introduction contains the definition of ice and snow, and a body of science that studies ice and snow; (2) Chapter II Natural Ice contains the process of ice formation along with the physical properties it shows and the existence of ice on Earth; (3) Chapter III Snow contains the process of forming snow and the positive and negative effects of snow; (4) Chapter IV Ice Skating contains about ice skating in Indonesia, the process of forming an ice skating arena, and ice skating equipment that must be used; and (5) Chapter V of the Cover contains the negative effects that will be caused by the absence of ice on Earth.

Physical studies on the books developed have links to physics high school material including temperature and heat, static fluid, optics, thermodynamics, rotational dynamics, even the colligative nature of solutions. The knowledge enrichment book developed also has several components that differentiate it from books in general such as the "Unique Fact" component which contains interesting information about the material being studied, the "Let's Try" component that invites readers to carry out simple experiments related to the material being studied, as well as the "Profile" component which contains an influential figure in the scientific field.

The book developed is also equipped with a cover that has a combination of the title of the book, the picture, and the basic colors used, so that it will attract readers. The book developed also has images that make the reader feel interested and motivated to learn. Besides, the books developed also use communicative language, so that readers will not feel bored.

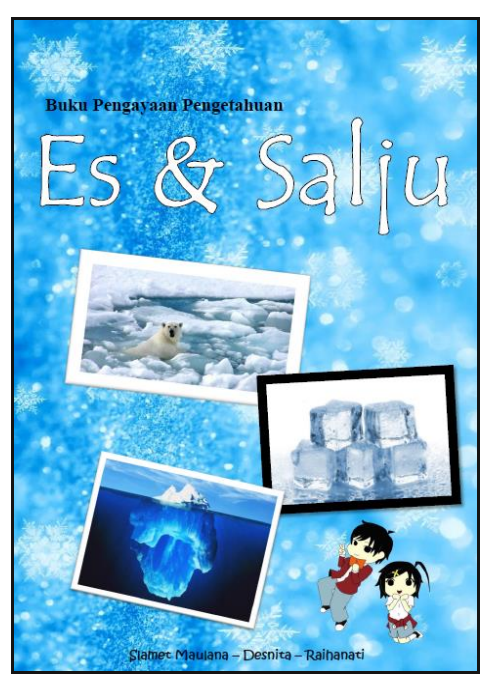

(a)

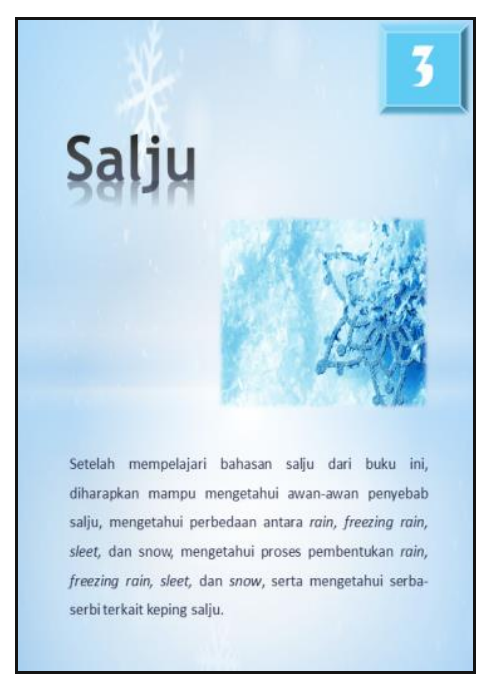

(b)

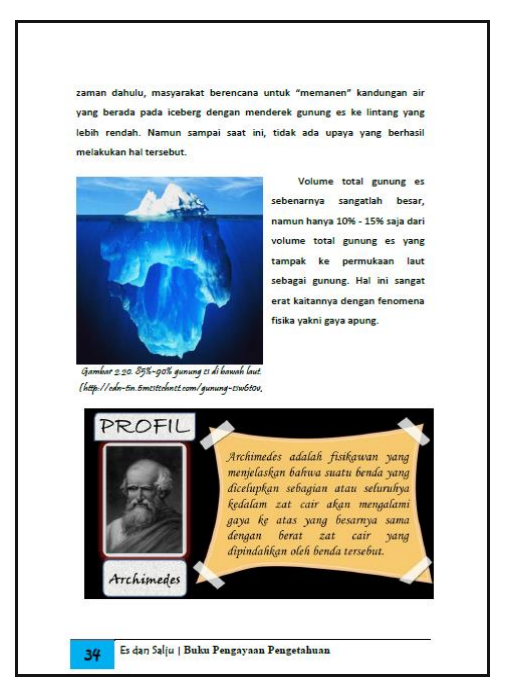

(c)

FIGURE 1. (a) Book cover, (b) Chapter cover, dan (c) Display of content of the book.

\section{Feasibility Test}

The knowledge enrichment book developed was tested for feasibility based on three aspects, they are the material aspect, media aspect, and learning aspect. The results of the feasibility test for the books developed by material experts were $94.12 \%$, media experts were $87.50 \%$, and learning experts were $92.04 \%$ with the interpretation of the three being "very good." 


\section{Feasibility Test}

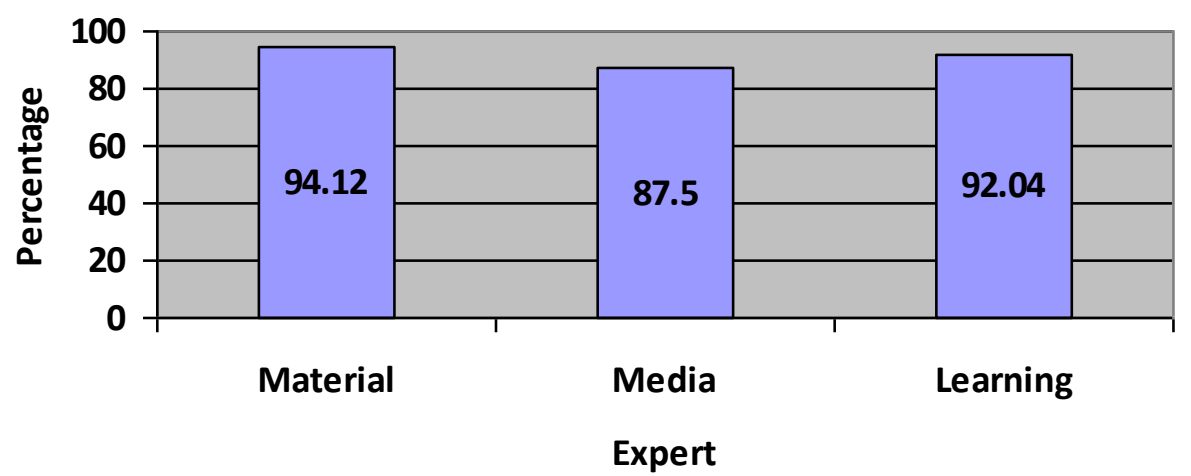

FIGURE 2. Feasibility Test Chart

Material experts consist of 4 aspects, namely the accuracy of the material by $100 \%$, supporting learning material by $100 \%$, the material content of $95.83 \%$, and material updating by $75 \%$. Media experts consist of 3 aspects, which are $85 \%$ presentation, $90 \%$ language, and $75 \%$ graphics. Learning experts include of 4 elements, namely material at $90 \%$, presentation at $89.28 \%$, language at $93.75 \%$, and graphics at $95.83 \%$.

\section{Product Trial Test}

Knowledge enrichment books developed after being tested for feasibility will then be tested on a product trial test with respondents consisting of 30 high school students. The results of product trials in the field for the books developed were $90.06 \%$ with a "excellent" interpretation where the material aspects were $89.58 \%$, language aspects were $90.21 \%$, and presentation aspects were $90.5 \%$.

\section{Product Trial Test}

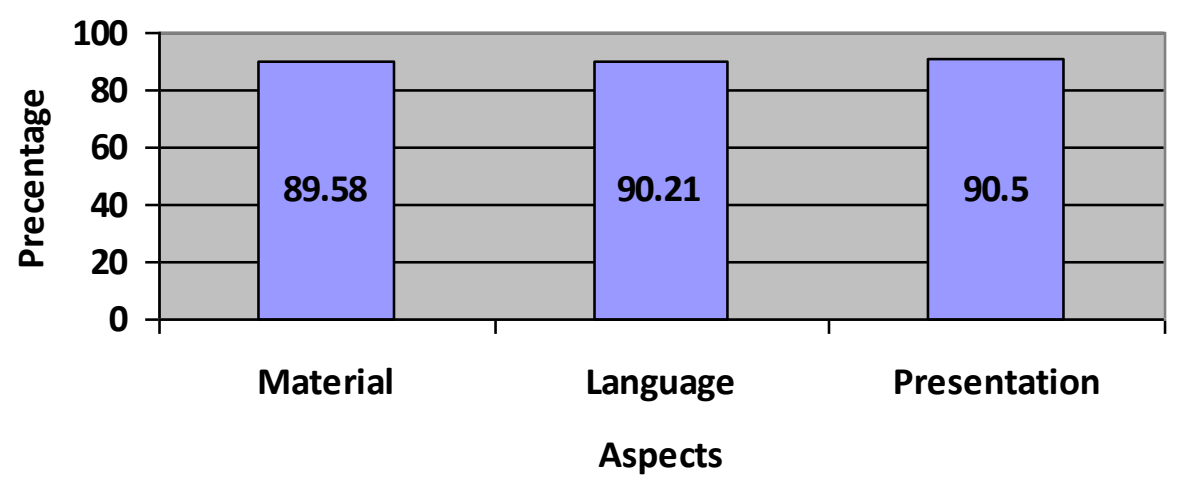

FIGURE 3. Product Trial Test Chart

\section{Discussion}

The feasibility tests carried out by the material experts to find out the quality of the enrichment book that has been developed regarding material. Based on the average score of $94.12 \%$ that has been given by material experts, the enrichment book that has been developed has excellent quality regarding material. Feasibility tests by media experts are carried out to determine the quality of 
knowledge enrichment books that have been developed regarding media. Based on the average score of $87.50 \%$ given by media experts, the enrichment books that have been developed have very good quality regarding media. Feasibility tests by learning experts are carried out to determine the quality of knowledge enrichment books that have been developed concerning learning. Based on the average score of $92.04 \%$ that has been given by learning experts, the enrichment books that have been developed have excellent quality concerning learning.

The results of the feasibility test by the three experts (material experts, media experts, and learning experts) stated that the three experts gave excellent categories. It means that both from the scientific point of view of physics, as a medium and source of learning, as well as facilities and infrastructure that teach students, these assessments signal that the knowledge enrichment books that have been developed are worthy of being tested in the field.

Product testing aims to decide that the product development is appropriate and feasible with the objectives to be achieved. The results of this trial are used to determine the acceptability and feasibility of the product so that it can be seen whether the product that has been developed is feasible as teaching material or not. The results of testing the product of knowledge enrichment books in groups of students showed an average percentage of $90.06 \%$ with excellent interpretation. It indicates that the knowledge enrichment book that has been developed is appropriate to be used as teaching material for students.

The results of product trials also show that students have more interest and motivation to learn more about the phenomenon of ice and snow. It is in line with some previous studies stating that enrichment books can enrich the insights and knowledge that follows developments in current science (Jayanti 2015, 66), (Maryam 2012, 48), (Mariana and Graduates 2018, 51). It is also the same as that issued by the Center for Curriculum and Bookkeeping which states that knowledge enrichment books intended for students can enrich their knowledge and understanding, both outward knowledge and inner knowledge (Curriculum and Bookkeeping Center 2014).

Based on the results of the feasibility test by the three experts, the enrichment books that have been developed can be declared appropriate for use as physics teaching materials with feasibility criteria for content, media, and learning very well. Whereas based on the results of product trials in the field, enrichment books that have been developed are accepted by students to be used as physics teaching materials.

\section{CONCLUSIONS}

Based on the feasibility test by the three experts (material, media, and learning) and product testing in the high school level environment, it can be concluded that the enrichment book on physical studies of ice and snow is suitable to be accepted by students as enrichment teaching material in the eye high school physics lessons.

\section{REFERENCES}

Al-Zoubi, SM 2014 'Effects of Enrichment Programs on the Academic Achievement of Gifted and Talented Students,' Journal for the Education of the Young Scientist and Giftedness, 2(2), pp. 2227.

Andriani, EYS, Mardikantoro, HB 2018, 'Pengembangan Buku Pengayaan Keterampilan Menulis Permulaan yang Bermuatan Nilai Karakter pada Peserta Didik Kelas I SD', Jurnal Pendidikan Bahasa dan Sastra Indonesia, 3(1), pp. 27-33.

Ary, D 2010, Introduction to Research in Education. 8th ed. s.l, Wadsworth Cengage Learning.

Astra, I, Saputra, F 2018, 'The Development of a Physics Knowledge Enrichment Book "Optical Instrument Equipped with Augmented Reality" to Improve Students' Learning Outcomes. s.l', Journal of Physics: Conference Series.

Ernawati, D, Ikhsan, J 2017, 'The Development of Monograph with 3-Dimentional Illustrations Titled "Augmented Chemistry: Hydrocarbon" as Learning Enrichment Materials. s.l', Journal of Physics: Conference Series. 
Fahmi, Z 2015, 'Pengembangan Buku Pengayaan Memproduksi Teks Fabel Bermuatan Nilai Budaya Untuk Siswa SMP’, Seloka: Jurnal Pendidikan Bahasa dan Sastra Indonesia, 4(2), pp. 86-93.

Izzati, N 2015, 'Pengaruh Penerapan Program Remedial Dan Pengayaan Melalui Pembelajaran Tutor Sebaya Terhadap Hasil Belajar Matematika Siswa', Eduma, 4(1), pp. 54-68.

Jayanti, T 2015, 'Pengembangan Buku Pengayaan Menulis Cerita Biografi Bermuatan Nilai-Nilai Pendidikan Karakter Bagi Peserta Didik Kelas VIII SMP', SELOKA, 4(2), pp. 65-71.

Mariana, F, Wisudawati, AW 2018, 'The Development of Ethnoscience-Based Chemical Enrichment Book as a Science Literacy Source of Students', International Journal of Chemistry Education Research, 2(1), pp. 50-57.

Maryam, S 2012, 'Strengthening the Character: Uphold Ethics in Indonesian Language Study Pass by Supplementary Books', International Journal for Educational Studies, 5(1), pp. 39-50.

Mulyatiningsih, E 2011, Riset Terapan Bidang Pendidikan dan Teknik, UNY Press, Yogyakarta.

Pemerintah Pendidikan Nasional 2008, Peraturan Pemerintah Pendidikan Nasional Nomor 2 Tahun 2008 tentang Buku, Pemerintah Pendidikan Nasional, Jakarta.

Pusat Kurikulum dan Perbukuan 2014, Pedoman Penilaian Buku Nonteks Pembelajaran, Badan Penelitian dan Pengembangan Kementerian Pendidikan dan Kebudayaan, Jakarta.

Rediati, A 2015, 'Pengembangan Buku Pengayaan Cara Menulis Teks Penjelasan Bermuatan Nilai Budaya Lokal untuk Peserta Didik Kelas V Sekolah Dasar' Seloka: Jurnal Pendidikan Bahasa dan Sastra Indonesia, 4(1), pp. 1-7.

Sanova, YZ, Hartono, Y 2017, 'Pengembangan Soal Pengayaan Matematika Online untuk Siswa Kelas X', Jurnal Elemen, 3(1), pp. 58-67. 
